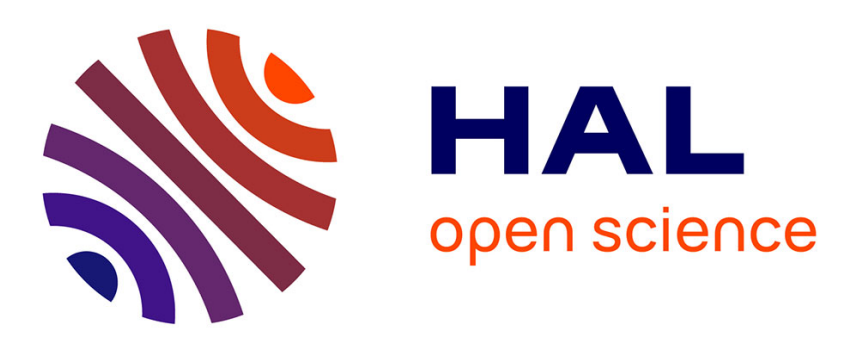

\title{
Biodiesel production from jatropha seeds: Solvent extraction and in situ transesterification in a single step
}

Ika Amalia Kartika, Muhammad Yani, Danu Ariono, Philippe Evon, Luc

Rigal

\section{- To cite this version:}

Ika Amalia Kartika, Muhammad Yani, Danu Ariono, Philippe Evon, Luc Rigal. Biodiesel production from jatropha seeds: Solvent extraction and in situ transesterification in a single step. Fuel, 2013, vol. 106, pp. 111-117. 10.1016/j.fuel.2013.01.021 . hal-00815301

\section{HAL Id: hal-00815301 \\ https://hal.science/hal-00815301}

Submitted on 18 Apr 2013

HAL is a multi-disciplinary open access archive for the deposit and dissemination of scientific research documents, whether they are published or not. The documents may come from teaching and research institutions in France or abroad, or from public or private research centers.
L'archive ouverte pluridisciplinaire HAL, est destinée au dépôt et à la diffusion de documents scientifiques de niveau recherche, publiés ou non, émanant des établissements d'enseignement et de recherche français ou étrangers, des laboratoires publics ou privés. 


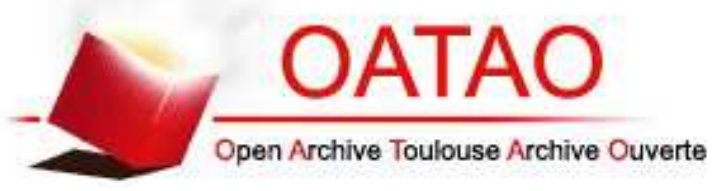

\section{Open Archive Toulouse Archive Ouverte (OATAO)}

OATAO is an open access repository that collects the work of Toulouse researchers and makes it freely available over the web where possible.

This is an author-deposited version published in: http://oatao.univ-toulouse.fr/ Eprints ID: 8587

To link to this article: DOI: $10.1016 / \mathrm{j}$. fuel.2013.01.021

URL: http://dx.doi.org/10.1016/j.fuel.2013.01.021

To cite this version: Amalia Kartika, Ika and Yani, Muhammad and Ariono, Danu and Evon, Philippe and Rigal, Luc Biodiesel production from jatropha seeds: Solvent extraction and in situ transesterification in a single step. (2013) Fuel, vol. 106 . pp. 111-117. ISSN 0016-2361

Any correspondence concerning this service should be sent to the repository administrator: staff-oatao@ listes-diff.inp-toulouse.fr 


\title{
Biodiesel production from jatropha seeds: Solvent extraction and in situ transesterification in a single step
}

\author{
I. Amalia Kartika ${ }^{\mathrm{a}, *}$, M. Yani ${ }^{\mathrm{a}}$, D. Ariono ${ }^{\mathrm{b}}$, Ph. Evon ${ }^{\mathrm{c}, \mathrm{d}}$, L. Rigal $^{\mathrm{c}, \mathrm{d}}$ \\ ${ }^{a}$ Department of Agroindustrial Technology, FATETA-IPB, Darmaga Campus, P.O. Box 220, Bogor 16002, Indonesia \\ ${ }^{\mathrm{b}}$ Department of Chemical Engineering, FTI-ITB, Ganesha 10 Road, Bandung 40132, Indonesia \\ ${ }^{\mathrm{c}}$ Université de Toulouse, INP, LCA (Laboratoire de Chimie Agro-Industrielle), ENSIACET, 4 allée Émile Monso, BP 44362, Toulouse 31030 Cedex 4, France \\ ${ }^{\mathrm{d}}$ INRA, LCA (Laboratoire de Chimie Agro-industrielle), Toulouse 31030, France
}

\section{H I G H L I G H T S}

- We investigate the biodiesel production directly from jatropha seeds.

- We examine influences of reaction conditions on biodiesel yield and its quality.

- Increasing methanol to seed ratio and alkali concentration will increase yield and quality.

- Increasing reaction temperature will increase yield.

- Temperature, time and stirring speed effects on biodiesel quality were less important.

\section{A R T I C L E I N F O}

\section{Article history:}

Received 31 March 2011

Received in revised form 10 October 2012

Accepted 9 January 2013

Available online 31 January 2013

\section{Keywords:}

Biodiesel

Jatropha seed

In situ transesterification

Solvent extraction

\begin{abstract}
A B S T R A C T
The objective of this study was to investigate solvent extraction and in situ transesterification in a single step to allow direct production of biodiesel from jatropha seeds. Experiments were conducted using milled jatropha seeds, and $n$-hexane as extracting solvent. The influence of methanol to seed ratio (2:1-6:1), amount of alkali $(\mathrm{KOH})$ catalyst (0.05-0.1 mol/L in methanol), stirring speed (700-900 rpm), temperature $\left(40-60^{\circ} \mathrm{C}\right.$ ) and reaction time (3-5 h) was examined to define optimum biodiesel yield and biodiesel quality after water washing and drying. When stirring speed, temperature and reaction time were fixed at $700 \mathrm{rpm}, 60{ }^{\circ} \mathrm{C}$ and $4 \mathrm{~h}$ respectively, highest biodiesel yield (80\% with a fatty acid methyl ester purity of $99.9 \%$ ) and optimum biodiesel quality were obtained with a methanol to seed ratio of $6: 1$ and $0.075 \mathrm{~mol} / \mathrm{L} \mathrm{KOH}$ in methanol. Subsequently, the influence of stirring speed, temperature and reaction time on biodiesel yield and biodiesel quality was studied, by applying the randomized factorial experimental design with ANOVA ( $F$-test at $p=0.05$ ), and using the optimum values previously found for methanol to seed ratio and $\mathrm{KOH}$ catalyst level. Most experimental runs conducted at $50{ }^{\circ} \mathrm{C}$ resulted to high biodiesel yields, while stirring speed and reaction time did not give significantly effect. The highest biodiesel yield ( $87 \%$ with a fatty acid methyl ester purity of $99.7 \%$ ) was obtained with a methanol to seed ratio of $6: 1, \mathrm{KOH}$ catalyst of $0.075 \mathrm{~mol} / \mathrm{L}$ in methanol, a stirring speed of $800 \mathrm{rpm}$, a temperature of $50{ }^{\circ} \mathrm{C}$, and a reaction time of $5 \mathrm{~h}$. The effects of stirring speed, temperature and reaction time on biodiesel quality were not significant. Most of the biodiesel quality obtained in this study conformed to the Indonesian Biodiesel Standard.
\end{abstract}

\section{Introduction}

Jatropha curcas is a drought-resistant shrub or tree belonging to the family Euphorbiaceae, which is cultivated in Central and South America, South-East Asia, India and Africa [1]. It is a plant with many attributes, multiple uses and considerable potential [2-4]. In Indonesia, the land area for jatropha plantation is increasing be-

\footnotetext{
* Corresponding author. Tel.: +62 251 8621974; fax: +62 2518625088.

E-mail address: ikatk@yahoo.com (I. Amalia Kartika).
}

cause this plant can be used to reclaim land, prevent and/or control erosion, plus it provides a new agricultural development mode with no competition between food and non-food uses.

The seed is the part of the jatropha plant with the highest potential for utilization. It contains between $40 \%$ and $60 \%$ oil, and between $20 \%$ and $30 \%$ proteins. The jatropha seed is generally toxic to humans and animals, with phorbol ester and curcin identified as the main toxic agents [1,5].

J. curcas oil is regarded as a potential alternative to diesel fuel, and vegetable oils have numerous advantages in this respect 
because they are safe to store and handle because of their high flash points. The fact that jatropha oil cannot be used for nutritional purposes without detoxification makes its use as an energy source for fuel production, very attractive [6,7].

In Indonesia, the availability of biofuel as a substitute for fossil fuel is urgently needed because national oil production has been falling over the past 5 years due to the natural decline of oil wells. The use of biodiesel from jatropha oil is a promising alternative because it is renewable, and environmentally friendly, and it can also be produced locally. Cultivating jatropha plants on land where no other crops can grow, and using its oil as an alternative energy source does not, at least in theory, reduce the availability of edible oils in the country.

Conventional industrial technology for the synthesis of biodiesel from vegetable oils involves isolation of the oil from the seed, refining, and then transesterification. Industrial oil extraction from oilseeds is usually done by mechanical pressing with a hydraulic or single expeller press, followed by solvent extraction. The combination of these operations produces oil extraction yields up to $98 \%$ in the case of sunflower, with residual oil content in cake meal between $0.5 \%$ and $1.5 \%$ [8]. The solvent extraction most commonly used today is by percolation with a countercurrent flow using hexane as extracting solvent [9-13]. Currently, twin-screw extrusion has been successfully carried out to extract oil from oilseeds [1419], and to conduct mechanical pressing and solvent extraction of sunflower oil in a single step [20]. Highest oil extraction yield (98\%) with best cake meal quality (residual oil content lower than $3 \%$ ) was obtained using a screw rotation speed of $185 \mathrm{rpm}$, feed rate of $30 \mathrm{~kg} / \mathrm{h}$, and solvent-to-solid ratio of 0.55 . Industrial oil refining normally includes many separate steps including degumming, neutralization, bleaching and deodorisation. These processes consume large amounts of energy, water and chemicals with much loss of neutral oil, and the production of large amounts of unwanted by-products [21].

The preparation of biodiesel from various vegetable oils using alkaline transesterification of triglycerides with monohydric alcohol has been studied for several decades, and a large part of industrial production has been achieved using this method [22,23], although it requires extra-steps during the extraction and refining processes. As the cost of vegetable oil production accounts for approximately $70 \%$ of biodiesel production costs [24-26], there is a need for the development of a new biodiesel production process that is simple, compact, efficient, low-cost, and that consumes less energy.

Recently, the preparation of biodiesel using in situ transesterification has been successfully carried out with various oilseeds [2432]. In situ transesterification is a biodiesel production method that uses the original agricultural products as the source of triglycerides, instead of purified oil, with direct transesterification, and works with virtually any lipid-bearing material. It reduces the time-consuming pre-extracted oil production system, and maximizes ester yield.

The conversion of jatropha seed to fatty acid methyl esters (FAME) by acid-catalyzed in situ transesterification has been successfully carried out [31]. Using seed size less than $0.355 \mathrm{~mm}$ and $n$-hexane as co-solvent under reaction conditions of $60^{\circ} \mathrm{C}$ temperature, for $24 \mathrm{~h}, 7.5 \mathrm{~mL} / \mathrm{g}$ methanol to seed ratio, and $15 \mathrm{wt} . \%$ of $\mathrm{H}_{2} \mathrm{SO}_{4}$, the FAME yield reached $99.8 \%$. However, the conversion of jatropha oil to FAME by in situ alkaline transesterification has never been reported. Thus, a systematic study should be conducted to investigate and identify optimal reaction conditions for single step in situ alkaline transesterification combined with solvent extraction of jatropha oil.

The objective of this study was thus to investigate solvent extraction and in situ transesterification in a single step to produce biodiesel directly from jatropha seeds. The influence of methanol to seed ratio, amount of alkali $(\mathrm{KOH})$ catalyst, stirring speed, temperature and reaction time was examined to identify the optimal reaction conditions and define best performance of biodiesel yield and quality.

\section{Materials and methods}

\subsection{Materials}

All trials were carried out using jatropha seeds (IP2 Lampung variety) supplied by the Indonesian Spices and Industrial Crops Research Institute (Sukabumi, Indonesia), and shells were removed manually before the study. Seed moisture content at storage was $6.2 \pm 0.5 \%$ (standard NF V 03-909) [33]. Methanol (>98\% purity) and $n$-hexane ( $>98 \%$ purity) were supplied by BRATACO Chemical Ltd. (Indonesia), and all analysis solvents and chemicals were pure analytical grades obtained from Sigma-Aldrich, Fluka and J.T. Baker (Indonesia and France).

\subsection{Experimental}

For all trials, moisture content determined by weight loss according to standard NF V 03-909 [33] and mesh size of jatropha seeds were less than $1 \%$ and 35 , respectively. To obtain a moisture content of less than $1 \%$, jatropha seeds were dried at $70-90^{\circ} \mathrm{C}$ for 24-48 h, and then milled using an electric grinder fitted with a mesh size of 35 .

The effect of methanol to seed ratio and amount of $\mathrm{KOH}$ on biodiesel yield and biodiesel quality was studied first. $100 \mathrm{~g}$ of milled jatropha seeds were mixed with methanol in which $\mathrm{KOH}$ had been dissolved. The methanol to seed ratio ( $\mathrm{v} / \mathrm{w}$, expressed in $\mathrm{mL} / \mathrm{g}$ ) and the amount of $\mathrm{KOH}$ in methanol were $2: 1-6: 1$ and $0.05-0.1 \mathrm{~mol} / \mathrm{L}$, respectively. The amount of $\mathrm{KOH}$ used in this study was based on literature values [30]. $100 \mathrm{~mL}$ of $n$-hexane (seed to $n$-hexane ratio $(\mathrm{w} / \mathrm{v})$ of $1: 1)$ was then added to increase oil miscibility in the mixture, accelerate the reaction and complete it in a single phase. The reaction was carried out in a three-necked $2000 \mathrm{~mL}$ round bottom flask equipped with a reflux system, a magnetic stirrer and a heater, under reaction conditions of $700 \mathrm{rpm}$ stirring speed, $60^{\circ} \mathrm{C}$ temperature and $4 \mathrm{~h}$ reaction duration.

At the end of the reaction period, the mixture was cooled to room temperature, and vacuum filtered to separate the filtrate from the cake. The filtrate was then evaporated using a rotary evaporator to recover methanol and $n$-hexane, and allowed to settle and separate into two layers. The lower layer was dark brown in color and contained glycerol, while the upper layer (crude biodiesel) was yellow in color and contained the fatty acid methyl esters, the unreacted glycerides (triglycerides, diglycerides and monoglycerides), and other impurities. Methanol and $n$-hexane may extract materials other than triglycerides, such as fatty acids and phospholipids. The crude biodiesel was then washed with water until neutrality, and dried at $105^{\circ} \mathrm{C}$ for $1 \mathrm{~h}$. The fatty acid methyl ester, triglyceride, diglyceride, monoglyceride and fatty acid contents in crude biodiesel after washing and drying were then determined by gas chromatography. The mass of crude biodiesel after washing and drying was measured, and the biodiesel yield was calculated from the equation:

Biodiesel yield $(\%)=\frac{\text { Mass of crude biodiesel after washing and drying }(\mathrm{g})}{\text { Mass of triglycerides in jatropha seeds }(\mathrm{g})}$

$$
\times 100
$$

with Mass of triglycerides in jatropha seeds $(\mathrm{g})=$ Mass of oil contained in jatropha seeds $(\mathrm{g}) \times$ Glyceride fraction content in jatropha oil $(\%) \times$ Triglyceride content in glyceride fraction (\%). The biodiesel yield is calculated on the basis of a pure biodiesel (i.e. containing 
only fatty acid methyl esters). Taking into account the fact that components contained in the crude biodiesel are not only fatty acid methyl esters, such formula may lead to a potential source of error.

Each experiment was conducted twice to give an average biodiesel yield with corresponding standard deviation. After the filtrate separation, the cake was not washed with methanol to take out the esters, meaning that it still contained a part of the fatty acid methyl esters produced during the in situ transesterification. It was directly dried overnight at room temperature, and the total volatile matter content and the $n$-hexane extracted matter content (i.e. weight loss upon $n$-hexane extraction) were then determined according to standards [33,34], respectively. All determinations were carried out in duplicate.

The effect of three other operating conditions (stirring speed, temperature and reaction time) on biodiesel yield and biodiesel quality was studied in the second stage. The corresponding experiments were conducted using a methanol to seed ratio of $6: 1(\mathrm{v} / \mathrm{w})$ and $0.075 \mathrm{~mol} / \mathrm{L} \mathrm{KOH}$ in methanol. The stirring speed, the temperature and the reaction time were $700-900 \mathrm{rpm}, 40-60{ }^{\circ} \mathrm{C}$ and 3$5 \mathrm{~h}$, respectively. Sample collection and analyses were performed using the same procedure as for effect of methanol to seed ratio and amount of $\mathrm{KOH}$ on biodiesel yield and biodiesel quality. Each experiment was duplicated, and biodiesel yield was taken as the average with corresponding standard deviation. The randomized factorial experimental design with ANOVA (F-test at $p=0.05$ ) was used to study the effects of stirring speed, temperature and reaction time on biodiesel yield and biodiesel quality using SAS software.

\subsection{Analytical methods}

Seed oil content was determined according to standard NF V 03908 [34]. Ground seed was placed into an extraction thimble, and the oil was extracted using Soxhlet extraction apparatus with $n$-hexane for $6 \mathrm{~h}$. The solvent was then evaporated using rotary vacuum evaporator, and the remaining oil was weighed. Seed oil content was expressed as percent by mass of the dry matter.

The fatty acid composition of oil extracted from jatropha seed was determined by gas chromatography (GC) using the following FAME method. The sample analyzed (i.e. the oil extracted from jatropha seed using the Soxhlet extraction apparatus and $n$-hexane as extracting solvent) was diluted in tert-butyl methyl ether (TBME) (concentration of around $20 \mathrm{mg} / \mathrm{mL}$ ). A $100 \mu \mathrm{L}$ aliquot of the prepared sample was then converted to methyl esters using $50 \mu \mathrm{L}$ of $0.5 \mathrm{~mol} / \mathrm{L}$ trimethylsulphonium hydroxide (TMSH) in methanol. The GC (VARIAN 3800) was equipped with a flame ionization detector using helium as carrier gas $(1.2 \mathrm{~mL} / \mathrm{min})$. The sample injected (i.e. methyl esters) was separated in a CP Select CB (VARIAN) column $(50 \mathrm{~m} \times 0.25 \mathrm{~mm})$. GC oven temperature was programmed at $185^{\circ} \mathrm{C}$ for $40 \mathrm{~min}$, then increased at a rate of $15^{\circ} \mathrm{C} \mathrm{min}{ }^{-1}$ to $250^{\circ} \mathrm{C}$, and then maintained at $250{ }^{\circ} \mathrm{C}$ for $11.68 \mathrm{~min}$. Injector temperature was programmed at $250^{\circ} \mathrm{C}$ for $55 \mathrm{~min}$, and detector temperature set at $250^{\circ} \mathrm{C}$.

The glyceride fraction content in jatropha oil and its composition (i.e. distribution between triglycerides, diglycerides, monoglycerides, and free fatty acids) was also determined by GC using the following method. $1.5 \mathrm{mg}$ of the sample analyzed (i.e. the oil extracted from jatropha seed using the Soxhlet extraction apparatus and $n$-hexane as extracting solvent) was diluted in $1 \mathrm{~mL}$ of chloroform. $20 \mu \mathrm{L}$ of silylation reagent (a mixture of $1 \mathrm{~mL}$ of $\mathrm{N}$ methyl-N-trimethylsilyl-heptafluorobutyramide (MSHFBA) and $50 \mu \mathrm{L}$ of 1 -methyl imidazole) was added to a $180 \mu \mathrm{L}$ aliquot of the prepared sample, and then heated at $103^{\circ} \mathrm{C}$ for $3 \mathrm{~min}$. The GC (Perkin Elmer) was equipped with a flame ionization detector using helium as carrier gas, and the injected sample was separated in a CP Sil 8CB (VARIAN) column $(15 \mathrm{~m} \times 0.32 \mathrm{~mm})$. GC oven tem- perature was programmed from $55^{\circ} \mathrm{C}$ to $360{ }^{\circ} \mathrm{C}$ at a rate of $45^{\circ} \mathrm{C} \mathrm{min}^{-1}$ to $80^{\circ} \mathrm{C}$, followed by $10^{\circ} \mathrm{C} \mathrm{min}^{-1}$, and was then maintained at $360{ }^{\circ} \mathrm{C}$ for $16 \mathrm{~min}$. Injector temperature was programmed from $55^{\circ} \mathrm{C}$ to $340{ }^{\circ} \mathrm{C}$ at a rate of $200{ }^{\circ} \mathrm{C} \mathrm{min}^{-1}$ and then maintained at $340^{\circ} \mathrm{C}$ for $40 \mathrm{~min}$, and detector temperature was set at $365^{\circ} \mathrm{C}$. Heptadecane was used as the internal standard. The peaks corresponding to the different glycerides and free fatty acids were identified by comparing the retention times of each detected component in the sample with the ones of pure glyceride and fatty acid standard compounds. To quantify each compound family (triglycerides, diglycerides, monoglycerides and free fatty acids) in the sample, a stock solution of triolein, diolein, monoolein and oleic acid added in the same proportions was prepared and then diluted to different concentrations. Stock solution and diluted solutions were used to obtain standard curves relating each peak area to the actual amounts of triolein, diolein, olein and oleic acid. For each of the four families above mentioned, the compound mass in the sample was obtained first by summing the peak areas from all same-family compounds, and then by relating area sums to standard curves. In each family, response factor of all the compounds was considered to be the same as the one of the corresponding oleic compound. The ratio between the sum of masses for triglycerides, diglycerides, monoglycerides and free fatty acids and the test sample mass was used to determine the glyceride fraction content in jatropha oil. The glyceride distribution between the four compound types was also calculated.

Once the biodiesel produced, its quality was analyzed. It includes the following parameters: (i) its acid value, expressed in $\mathrm{mg}$ of $\mathrm{KOH} / \mathrm{g}$ of sample (standard NF T 60-204) [35], which is an indication of the free fatty acid content of the sample, (ii) its saponification value, expressed in $\mathrm{mg}$ of $\mathrm{KOH} / \mathrm{g}$ of sample (standard NI 01-3555-1998) [36], which is the amount of alkali necessary to saponify a certain quantity of the sample, (iii) its iodine value, expressed as the number of centigrams of iodine absorbed per gram of sample (standard AOCS-Cd 1d-92) [37], which is a measurement of the unsaturations of the sample, and (iv) its viscosity, estimated using the AOAC 974:07 method [38] with an Ostwald viscometer, measured at $40^{\circ} \mathrm{C}$.

In addition, the biodiesel fatty acid methyl ester content was determined by gas chromatography using the method described as follows. The sample was diluted in cyclohexane (concentration of around $8 \mathrm{mg} / \mathrm{mL}$ ). The GC (Perkin Elmer Autosystem XL) was equipped with a flame ionization detector using helium as carrier gas, and the injected sample was separated in a VF-5 ms (VARIAN) column $(15 \mathrm{~m} \times 0.32 \mathrm{~mm})$. GC oven temperature was programmed from $55^{\circ} \mathrm{C}$ to $360{ }^{\circ} \mathrm{C}$ at a rate of $45^{\circ} \mathrm{C} \mathrm{min}^{-1}$ to $80^{\circ} \mathrm{C}$, followed by $10^{\circ} \mathrm{C} \mathrm{m^{-1 }}$, and was then maintained at $360^{\circ} \mathrm{C}$ for $15 \mathrm{~min}$. Injector temperature was programmed from $55^{\circ} \mathrm{C}$ to $340{ }^{\circ} \mathrm{C}$ at a rate of $200{ }^{\circ} \mathrm{C} \mathrm{min}^{-1}$ and then maintained at $340^{\circ} \mathrm{C}$ for $35 \mathrm{~min}$, and detector temperature was set at $365^{\circ} \mathrm{C}$. Methyl heptadecanoate was used as the internal standard. The peaks of different methyl esters were identified by comparing the retention time of each component in the sample with the peaks of pure methyl ester standard compounds.

The biodiesel produced under the optimal reaction conditions was completely characterized in accordance with Indonesian Biodiesel Standard [39]. All determinations were carried out in duplicate.

\section{Results and discussion}

In transesterification reactions with alkaline catalysts, the presence of water can cause ester saponification. Thus jatropha seeds with less than $1 \%$ moisture content were used in all experiments. Moreover, results from previous studies showed that this seed 
moisture content affected biodiesel yield [24,30,40], and that the latter increased as moisture content of jatropha seed was decreased [40]. In addition, this decrease in seed moisture content increased the amount of oil dissolved in methanol [30].

The oil content of the jatropha seed used in this study was $39.4 \pm 1.5 \%$ relative to its dry matter content (standard NF V 03908 ), and this agrees with the $22-48 \%$ results reported by some researchers $[4,41]$. The fatty acid composition of jatropha oil (FAME method) was palmitic $(14.7 \pm 0.2 \%)$, palmitoleic $(0.9 \pm 0.0 \%)$, stearic $(7.4 \pm 0.3 \%)$, oleic $(39.4 \pm 0.8 \%)$, linoleic $(36.5 \pm 0.9 \%)$, linolenic $(0.7 \pm 0.0 \%)$, arachidic $(0.2 \pm 0.0 \%)$, and gadoleic $(0.2 \pm 0.0 \%)$. Thus, the oil in this study was rich in oleic and linoleic fatty acids, like other jatropha oils described in the literature [1-5,41,42]. Its glyceride fraction content, i.e. the content of triglycerides, diglycerides, monoglycerides and free fatty acids in the oil, was $99.0 \pm 0.5 \%$, meaning that the unsaponifiable compounds such as sterols and tocopherols were minor compounds. It was composed of triglycerides $(95.8 \pm 0.2 \%)$, diglycerides $(2.6 \pm 0.1 \%)$ and monoglycerides $(0.3 \pm 0.0 \%)$, and it contained $1.4 \pm 0.1 \%$ of free fatty acids. These are carboxylic acids released from triglycerides via lipase or oxidation. There is a high risk of oxidation of the jatropha oil inside the seed due to its high unsaturated fatty acid content, especially oleic and linoleic, and those containing one or more of the non-conjugated pentadiene system $\left(-\mathrm{CH}=\mathrm{CH}-\mathrm{CH}_{2}-\mathrm{CH}=\mathrm{CH}-\right)$ are especially sensitive [43]. In alkaline transesterification, the free fatty acids quickly react with the catalyst to produce soaps that are difficult to separate, and this may reduce the quantity of catalyst available for transesterification, lowering the ester production yield. Soaps produced could cause an increase in viscosity, and the appearance of gels, and also make the separation of glycerol difficult [30]. Low free fatty acid content in the oil (less than 3\%) is therefore required for alkali-catalyzed transesterification [44]. An attractive way to control free fatty acids in the seed is by controlling its water activity $\left(a_{\mathrm{w}}\right)$ to a level that disables any undesirable reactions or enzyme activities. This means understanding seed characteristics and behavior in response to changes in environmental conditions, particularly relative humidity, which has been successfully applied to jatropha seed [45]. Thus, control of free fatty acids in the seed, can be achieved by proper handling and storage before oil extraction and in situ transesterification.

Simultaneous solvent extraction and in situ transesterification on biodiesel processing of jatropha seeds had a positive effect on both biodiesel yield and biodiesel quality. The main advantage of this combined process is that it allows solvent extraction to be applied to oilseeds and then in situ transesterification of the extracted oils. Methanol was not a very effective solvent for oil extraction due to its immiscibility. However, the addition of a cosolvent such as $n$-hexane into the reaction mixture can significantly improve mass transfer of oil into alcohol (methanol or ethanol) and also intensify the transesterification reaction between oil and alcohol $[31,32,46,47]$. $n$-Hexane is an efficient solvent for oil extraction from oilseeds and, in the case of jatropha seed, its non-polarity can also limit the removal of free fatty acids and water from the seed [47]. In this study, the ratio of $n$-hexane added to seed was 1:1 (volume/weight, expressed in $\mathrm{mL} / \mathrm{g}$ ) for all experiments.

As previously observed by some researchers [25,29,30,47], Fig. 1 shows that the methanol to seed ratio and the amount of alkali $(\mathrm{KOH})$ catalyst affected the biodiesel yield. For the three levels of $\mathrm{KOH}$ tested, a systematic increase in biodiesel yield was observed when the methanol to seed ratio increased from 2:1 to 6:1. In addition, for a methanol to seed ratio of $2: 1$, the biodiesel yield remained relatively stable (between $35 \%$ and $38 \%$ ), meaning that it did not depend on the amount of $\mathrm{KOH}$ in the methanol. Conversely, increasing the amount of $\mathrm{KOH}$ from 0.05 to $0.075 \mathrm{~mol} / \mathrm{L}$ in methanol significantly increased the biodiesel yield when the methanol

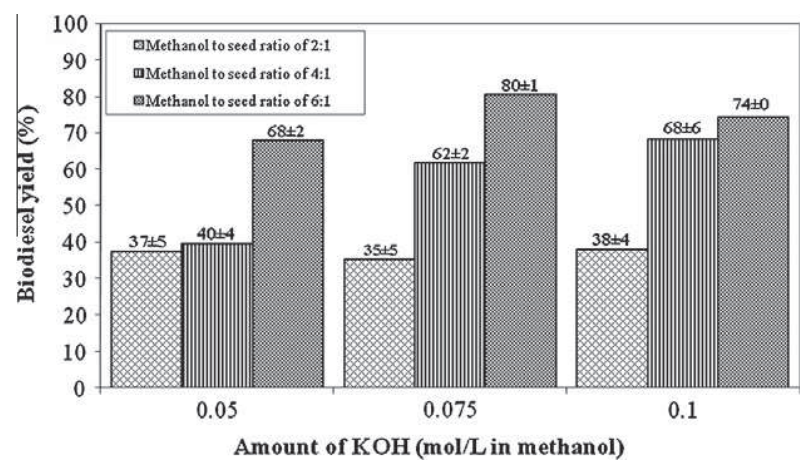

Fig. 1. Influence of methanol to seed ratio and amount of alkali $(\mathrm{KOH})$ catalyst on biodiesel yield ( $700 \mathrm{rpm}$ stirring speed, $60{ }^{\circ} \mathrm{C}$ temperature, and $4 \mathrm{~h}$ reaction time).

to seed ratio was at least $4: 1$. Thus, a methanol to seed ratio of only $2: 1$ was not sufficient for complete transesterification of the triglycerides released from jatropha seed. However, when the amount of $\mathrm{KOH}$ exceeded $0.075 \mathrm{~mol} / \mathrm{L}$ in methanol, it had less effect on the biodiesel yield, with only a slight increase when the methanol to seed ratio was $4: 1$ (from $62 \%$ to $68 \%$ ). For a methanol to seed ratio of $6: 1$, increasing the amount of $\mathrm{KOH}$ from 0.075 to $0.1 \mathrm{~mol} / \mathrm{L}$ in methanol even caused a drop in yield (from $80 \%$ to $74 \%$ ). Thus, $0.075 \mathrm{~mol} / \mathrm{L} \mathrm{KOH}$ in methanol is the optimal concentration of alkali catalyst. Excess catalyst gave rise to formation of an emulsion that increased the viscosity and led to the formation of a gel, lowering the ester production yield [48].

For the reaction conditions investigated (2:1-6:1 methanol to seed ratio, and $0.05-0.1 \mathrm{~mol} / \mathrm{L} \mathrm{KOH}$ in methanol), the best biodiesel yield ( $80 \%$ with a fatty acid methyl ester purity of $99.9 \%$ ) was therefore obtained with a methanol to seed ratio of 6:1 (expressed in $\mathrm{mL} / \mathrm{g}$ ) and $0.075 \mathrm{~mol} / \mathrm{L} \mathrm{KOH}$ in methanol. For comparison, the optimal molar ratio for conventional alkaline transesterification of different oils is of the order of 6:1 (expressed in $\mathrm{mol} / \mathrm{mol}$ ) at $60{ }^{\circ} \mathrm{C}[4,22,23,42,48,49]$. Thus, the in situ transesterification of jatropha oil from seed used about 17 times more methanol (lipid to methanol ratio of $1: 104$, expressed in $\mathrm{mol} / \mathrm{mol}$ ) than the conventional method (1:6). However, the excess reagents could be recovered for reuse.

Compared with acid-catalyzed in situ transesterification of jatropha oil from seed (over $12 \mathrm{~h}$ reaction time and $15 \mathrm{wt} . \%$ $\mathrm{H}_{2} \mathrm{SO}_{4}$ ) [31], the alkali-catalyzed process is faster and uses less reagents ( $4 \mathrm{~h}$ reaction time and $6.4 \mathrm{wt} . \% \mathrm{KOH}$ ). For $4 \mathrm{~h}$ reaction time, the yield obtained from acid-catalyzed in situ transesterification of jatropha oil from seed was only $40 \%$ [31] instead of $80 \%$ with the alkali-catalysed process described in this study. The greater yield with alkaline catalysis is consistent with its greater effectiveness in transesterification of triglycerides, and may also indicate better access of the transesterification reagent to the oil component of the seed, under alkaline conditions [25]. As observed in previous studies [25,30], alkaline alcohol could destroy intracellular compartments in oilseeds, allowing solubilisation and subsequent transesterification of triglycerides. In the present study, maximum ester yield ( $80 \%$ with a fatty acid methyl ester purity of $99.9 \%$ ) was achieved with a reaction time of $4 \mathrm{~h}$ and $6.4 \mathrm{wt} . \% \mathrm{KOH}$ (compared to the oil contained in the jatropha seed) or $0.075 \mathrm{~mol} / \mathrm{L}$ in methanol. For comparison, the amount of catalyst $(\mathrm{KOH})$ required for the conventional alkaline transesterification of different vegetable oils is $1 \%$ (based on oil weight) [48]. Thus, the in situ transesterification of jatropha oil from seed used about 6.4 times more $\mathrm{KOH}$ than the conventional method.

The biodiesel produced by in situ transesterification of jatropha oil from seed was of excellent quality using a methanol to seed ratio of 6:1 (Table 1). And, for this ratio, an increase in the amount of 
Table 1

Crude biodiesel quality at different methanol to seed ratios and amounts of alkali (KOH) catalyst ( $700 \mathrm{rpm}$ stirring speed, $60{ }^{\circ} \mathrm{C}$ temperature, and $4 \mathrm{~h}$ reaction time).

\begin{tabular}{|c|c|c|c|c|c|c|c|c|c|}
\hline \multirow{2}{*}{$\begin{array}{l}\text { Methanol to seed } \\
\text { ratio }(\mathrm{v} / \mathrm{w})\end{array}$} & \multirow{2}{*}{$\begin{array}{l}\text { Amount of } \mathrm{KOH}(\mathrm{mol} / \mathrm{L} \\
\text { in methanol) }\end{array}$} & \multirow{2}{*}{$\begin{array}{l}\text { Acid value (mg } \\
\mathrm{KOH} / \mathrm{g})\end{array}$} & \multirow{2}{*}{$\begin{array}{l}\text { Saponification value } \\
(\mathrm{mg} \mathrm{KOH} / \mathrm{g})\end{array}$} & \multirow{2}{*}{$\begin{array}{l}\text { Viscosity at } 40^{\circ} \mathrm{C} \\
\left(10^{-6} \mathrm{~m}^{2} / \mathrm{s}\right)\end{array}$} & \multicolumn{5}{|c|}{ Composition (wt.\%) } \\
\hline & & & & & FAME & MAG & DAG & TAG & FA \\
\hline $2: 1$ & 0.05 & $1.48 \pm 0.00$ & $212 \pm 4$ & $24.1 \pm 0.0$ & $3.0 \pm 0.1$ & $0.2 \pm 0.0$ & $4.1 \pm 0.1$ & $91.7 \pm 0.1$ & $1.0 \pm 0.1$ \\
\hline $2: 1$ & 0.075 & $1.48 \pm 0.00$ & $195 \pm 1$ & $21.9 \pm 3.5$ & $3.5 \pm 1.5$ & $0.1 \pm 0.0$ & $2.9 \pm 0.2$ & $91.9 \pm 1.6$ & $1.6 \pm 0.3$ \\
\hline $2: 1$ & 0.1 & $0.81 \pm 0.00$ & $193 \pm 1$ & $21.9 \pm 1.8$ & $8.3 \pm 0.8$ & $0.1 \pm 0.0$ & $2.5 \pm 0.1$ & $88.3 \pm 1.0$ & $0.8 \pm 0.0$ \\
\hline $4: 1$ & 0.05 & $0.27 \pm 0.00$ & $207 \pm 4$ & $21.5 \pm 1.2$ & $10.6 \pm 1.0$ & $0.3 \pm 0.1$ & $2.9 \pm 0.1$ & $85.4 \pm 1.0$ & $0.8 \pm 0.0$ \\
\hline $4: 1$ & 0.075 & $0.27 \pm 0.00$ & $215 \pm 1$ & $8.1 \pm 0.9$ & $56.2 \pm 3.5$ & $0.2 \pm 0.1$ & $2.0 \pm 0.0$ & $40.9 \pm 7.1$ & $0.7 \pm 0.1$ \\
\hline $4: 1$ & 0.1 & $0.27 \pm 0.00$ & $209 \pm 0$ & $3.7 \pm 0.0$ & $91.2 \pm 0.8$ & $0.1 \pm 0.0$ & $0.3 \pm 0.1$ & $8.1 \pm 1.3$ & $0.3 \pm 0.1$ \\
\hline $6: 1$ & 0.05 & $0.27 \pm 0.00$ & $215 \pm 2$ & $3.5 \pm 0.0$ & $99.6 \pm 0.1$ & $0.1 \pm 0.0$ & $0.0 \pm 0.0$ & $0.0 \pm 0.0$ & $0.3 \pm 0.1$ \\
\hline $6: 1$ & 0.075 & $0.27 \pm 0.00$ & $212 \pm 1$ & $3.4 \pm 0.1$ & $99.9 \pm 0.1$ & $0.0 \pm 0.0$ & $0.0 \pm 0.0$ & $0.0 \pm 0.0$ & $0.1 \pm 0.0$ \\
\hline $6: 1$ & 0.1 & $0.27 \pm 0.00$ & $193 \pm 1$ & $3.5 \pm 0.1$ & $99.7 \pm 0.5$ & $0.0 \pm 0.0$ & $0.0 \pm 0.0$ & $0.0 \pm 0.0$ & $0.2 \pm 0.1$ \\
\hline
\end{tabular}

FAME, fatty acid methyl esters; MAG, monoglycerides; DAG, diglycerides; TAG, triglycerides; FA, free fatty acids.

Table 2

Effect of operating conditions on process performance and crude biodiesel quality (6:1 methanol to seed ratio and $0.075 \mathrm{~mol} / \mathrm{L} \mathrm{KOH}$ in methanol).

\begin{tabular}{|c|c|c|c|c|c|c|c|c|}
\hline \multirow{2}{*}{$\begin{array}{l}\text { Stirring } \\
\text { speed (rpm) }\end{array}$} & \multirow{2}{*}{$\begin{array}{l}\text { Temperature } \\
\left({ }^{\circ} \mathrm{C}\right)\end{array}$} & \multirow{2}{*}{$\begin{array}{l}\text { Reaction } \\
\text { time }(\mathrm{h})\end{array}$} & \multirow{2}{*}{$\begin{array}{l}\text { Crude } \\
\text { yield } \\
\text { (wt.\%) }\end{array}$} & \multirow{2}{*}{$\begin{array}{l}\text { Acid value } \\
(\mathrm{mg} \mathrm{KOH} / \mathrm{g})\end{array}$} & \multirow{2}{*}{$\begin{array}{l}\text { Saponification } \\
\text { value }(\mathrm{mg} \mathrm{KOH} / \mathrm{g})\end{array}$} & \multirow{2}{*}{$\begin{array}{l}\text { Viscosity at } 40^{\circ} \mathrm{C} \\
\left(10^{-6} \mathrm{~m}^{2} / \mathrm{s}\right)\end{array}$} & \multicolumn{2}{|l|}{ Cake meal } \\
\hline & & & & & & & $\begin{array}{l}\text { Total volatile } \\
\text { matter content }(\%)\end{array}$ & $\begin{array}{l}n \text {-Hexane extracted } \\
\text { matter content }(\%)\end{array}$ \\
\hline 700 & 40 & 3 & $81 \pm 1$ & $0.49 \pm 0.10$ & $198 \pm 2$ & $3.6 \pm 0.0$ & $10.2 \pm 0.6$ & $14.6 \pm 2.8$ \\
\hline 800 & 40 & 3 & $82 \pm 3$ & $0.42 \pm 0.10$ & $190 \pm 6$ & $3.5 \pm 0.0$ & $9.8 \pm 0.9$ & $13.5 \pm 0.5$ \\
\hline 900 & 40 & 3 & $83 \pm 1$ & $0.49 \pm 0.10$ & $201 \pm 1$ & $3.5 \pm 0.0$ & $11.3 \pm 1.1$ & $14.8 \pm 0.5$ \\
\hline 700 & 50 & 3 & $83 \pm 1$ & $0.35 \pm 0.10$ & $197 \pm 5$ & $3.5 \pm 0.0$ & $10.7 \pm 0.3$ & $13.0 \pm 0.7$ \\
\hline 800 & 50 & 3 & $81 \pm 0$ & $0.28 \pm 0.00$ & $200 \pm 0$ & $3.5 \pm 0.0$ & $11.3 \pm 0.7$ & $11.9 \pm 1.4$ \\
\hline 900 & 50 & 3 & $82 \pm 2$ & $0.42 \pm 0.00$ & $200 \pm 4$ & $3.5 \pm 0.0$ & $10.0 \pm 0.3$ & $14.5 \pm 2.1$ \\
\hline 700 & 60 & 3 & $77 \pm 0$ & $0.35 \pm 0.10$ & $205 \pm 3$ & $3.5 \pm 0.1$ & $9.8 \pm 0.6$ & $14.7 \pm 1.7$ \\
\hline 800 & 60 & 3 & $83 \pm 3$ & $0.28 \pm 0.00$ & $199 \pm 1$ & $3.5 \pm 0.0$ & $11.1 \pm 0.2$ & $15.2 \pm 3.0$ \\
\hline 900 & 60 & 3 & $85 \pm 1$ & $0.28 \pm 0.00$ & $200 \pm 5$ & $3.5 \pm 0.0$ & $10.1 \pm 0.7$ & $14.3 \pm 1.7$ \\
\hline 700 & 40 & 4 & $79 \pm 2$ & $0.28 \pm 0.00$ & $197 \pm 2$ & $3.5 \pm 0.0$ & $11.2 \pm 1.8$ & $15.4 \pm 0.3$ \\
\hline 800 & 40 & 4 & $76 \pm 3$ & $0.28 \pm 0.00$ & $203 \pm 2$ & $3.5 \pm 0.0$ & $10.4 \pm 0.8$ & $14.0 \pm 0.9$ \\
\hline 900 & 40 & 4 & $83 \pm 2$ & $0.42 \pm 0.00$ & $201 \pm 1$ & $3.5 \pm 0.0$ & $10.9 \pm 0.6$ & $15.0 \pm 0.5$ \\
\hline 700 & 50 & 4 & $86 \pm 2$ & $0.42 \pm 0.00$ & $194 \pm 0$ & $3.5 \pm 0.0$ & $11.8 \pm 0.4$ & $15.8 \pm 2.4$ \\
\hline 800 & 50 & 4 & $83 \pm 0$ & $0.35 \pm 0.10$ & $194 \pm 0$ & $3.5 \pm 0.0$ & $11.5 \pm 0.4$ & $14.9 \pm 0.0$ \\
\hline 900 & 50 & 4 & $84 \pm 1$ & $0.49 \pm 0.10$ & $202 \pm 5$ & $3.5 \pm 0.0$ & $9.7 \pm 1.4$ & $11.5 \pm 2.0$ \\
\hline 700 & 60 & 4 & $76 \pm 1$ & $0.28 \pm 0.00$ & $200 \pm 4$ & $3.5 \pm 0.0$ & $10.6 \pm 0.7$ & $14.1 \pm 0.9$ \\
\hline 800 & 60 & 4 & $85 \pm 2$ & $0.42 \pm 0.00$ & $196 \pm 3$ & $3.5 \pm 0.0$ & $10.7 \pm 0.8$ & $14.7 \pm 0.0$ \\
\hline 900 & 60 & 4 & $75 \pm 3$ & $0.35 \pm 0.10$ & $200 \pm 0$ & $3.5 \pm 0.1$ & $9.1 \pm 0.2$ & $12.2 \pm 2.9$ \\
\hline 700 & 40 & 5 & $84 \pm 3$ & $0.42 \pm 0.00$ & $196 \pm 2$ & $3.5 \pm 0.0$ & $10.0 \pm 0.3$ & $15.6 \pm 0.8$ \\
\hline 800 & 40 & 5 & $83 \pm 2$ & $0.42 \pm 0.00$ & $198 \pm 3$ & $3.5 \pm 0.0$ & $10.6 \pm 0.7$ & $12.4 \pm 0.1$ \\
\hline 900 & 40 & 5 & $84 \pm 1$ & $0.28 \pm 0.00$ & $201 \pm 1$ & $3.5 \pm 0.1$ & $11.9 \pm 2.5$ & $13.8 \pm 1.2$ \\
\hline 700 & 50 & 5 & $85 \pm 1$ & $0.42 \pm 0.00$ & $200 \pm 2$ & $3.5 \pm 0.0$ & $10.0 \pm 0.4$ & $12.5 \pm 1.3$ \\
\hline 800 & 50 & 5 & $87 \pm 1$ & $0.35 \pm 0.10$ & $199 \pm 4$ & $3.5 \pm 0.0$ & $10.5 \pm 0.3$ & $13.9 \pm 1.8$ \\
\hline 900 & 50 & 5 & $85 \pm 0$ & $0.28 \pm 0.00$ & $198 \pm 1$ & $3.5 \pm 0.0$ & $9.4 \pm 0.2$ & $12.8 \pm 1.4$ \\
\hline 700 & 60 & 5 & $80 \pm 2$ & $0.28 \pm 0.00$ & $206 \pm 1$ & $3.5 \pm 0.0$ & $10.8 \pm 0.3$ & $14.9 \pm 0.8$ \\
\hline 800 & 60 & 5 & $76 \pm 1$ & $0.28 \pm 0.00$ & $203 \pm 4$ & $3.5 \pm 0.1$ & $10.2 \pm 0.3$ & $13.4 \pm 3.3$ \\
\hline 900 & 60 & 5 & $76 \pm 0$ & $0.28 \pm 0.00$ & $200 \pm 1$ & $3.5 \pm 0.0$ & $10.5 \pm 0.1$ & $13.7 \pm 0.8$ \\
\hline
\end{tabular}

$\mathrm{KOH}$ (from 0.05 to $0.1 \mathrm{~mol} / \mathrm{L}$ in methanol) had no significant influence on the biodiesel quality which remained excellent. The acid value and the viscosity remained stable at less than $0.3 \mathrm{mg}$ of $\mathrm{KOH} / \mathrm{g}$ of biodiesel and less than $3.510^{-6} \mathrm{~m}^{2} / \mathrm{s}$, respectively. Saponification value and fatty acid methyl ester purity were high (more than $190 \mathrm{mg}$ of $\mathrm{KOH} / \mathrm{g}$ of biodiesel and more than $99.6 \%$, respectively). These qualities would favor the use of such biodiesel as automotive fuel. The quality of the biodiesel obtained in this study was equivalent to that of one produced using the conventional method, and it conformed to the Indonesian Biodiesel Standard [39]. Moreover, the biodiesel quality was directly correlated to its yield. Indeed, best biodiesel quality was achieved with a methanol to seed ratio of 6:1 (Table 1 ) that also gave the best biodiesel yield (Fig. 1).

The quality of biodiesels produced by in situ transesterification of jatropha oil from seed with a methanol to seed ratio of less than 6:1 (Table 1) was relatively poor. Acid value and viscosity were high, whereas fatty acid methyl ester purity was low. Increasing the methanol to seed ratio and the amount of $\mathrm{KOH}$ in methanol im- proved the biodiesel quality. Acid value and viscosity decreased, and fatty acid methyl ester purity increased with an increase in methanol to seed ratio and amount of $\mathrm{KOH}$ in methanol. The saponification value remained stable at over $190 \mathrm{mg}$ of $\mathrm{KOH} / \mathrm{g}$ of biodiesel with increasing methanol to seed ratio and amount of $\mathrm{KOH}$ in methanol.

The influence of stirring speed, temperature and reaction time on biodiesel yield was studied using randomized factorial experimental design with three variables. For this study, methanol to seed ratio was $6: 1$, and $\mathrm{KOH}$ amount was $0.075 \mathrm{~mol} / \mathrm{L}$ in methanol. The results obtained are shown in Table 2 and generally, stirring speed, temperature and reaction time affected biodiesel yield. But here, applying ANOVA to actual data ( $F$-test at $p=0.05$ ) shows that the effect of temperature on biodiesel yield was more significant than the two others. Five of the seven best yields corresponded to experiments conducted at $50^{\circ} \mathrm{C}$, with different stirring speeds $(700-900 \mathrm{rpm})$ and different reaction times (4-5 h). Temperature can influence reaction rate and jatropha oil conversion, because intrinsic rate constants are largely dependent 
Table 3

Jatropha crude biodiesel quality produced under optimal reaction conditions (6:1 methanol to seed ratio, $0.075 \mathrm{~mol} / \mathrm{L} \mathrm{KOH}$ in methanol, $800 \mathrm{rpm}$ stirring speed, $50{ }^{\circ} \mathrm{C}$ temperature, and $5 \mathrm{~h}$ reaction time).

\begin{tabular}{|c|c|c|c|}
\hline Parameter & Unit & Jatropha biodiesel & Biodiesel standard [39] \\
\hline Density at $40^{\circ} \mathrm{C}$ & $\mathrm{g} / \mathrm{cm}^{3}$ & 0.885 & $0.850-0.890$ \\
\hline Viscosity at $40^{\circ} \mathrm{C}$ & $10^{-6} \mathrm{~m}^{2} / \mathrm{s}$ & 3.5 & $2.3-6.0$ \\
\hline Flash point & ${ }^{\circ} \mathrm{C}$ & 107 & $100 \mathrm{~min}$ \\
\hline Pour point & ${ }^{\circ} \mathrm{C}$ & 0 & $0 \max [60]$ \\
\hline Cloud point & ${ }^{\circ} \mathrm{C}$ & 11 & $18 \max$ \\
\hline Acid value & $\mathrm{mg} \mathrm{KOH} / \mathrm{g}$ & 0.35 & $0.8 \max$ \\
\hline Cetane number & - & 47 & $51 \mathrm{~min}$ \\
\hline Water and sediment content & wt.\% & Trace $(<0.05)$ & $0.05 \max$ \\
\hline Sulfated ash content & wt.\% & 0 & $0.02 \max$ \\
\hline Iodine number & $\mathrm{g}$ iodine $/ 100 \mathrm{~g}$ & 107 & $115 \max$ \\
\hline HHV & $\mathrm{MJ} / \mathrm{kg}$ & 40 & $35 \min [60]$ \\
\hline Composition: & wt.\% & & \\
\hline Fatty acid methyl esters & & 99.7 & $96.5 \min [60]$ \\
\hline Monoglyceride (MAG) & & 0.1 & $0.8 \max [60]$ \\
\hline Diglyceride (DAG) & & 0 & $0.2 \max [60]$ \\
\hline Triglyceride (TAG) & & 0 & $0.2 \max [60]$ \\
\hline
\end{tabular}

on temperature [47]. A higher temperature can decrease the viscosities of oils, can increase the solubility of reactants, and can result in an increased reaction rate and a shorter reaction time [23]. In addition, high temperatures favor reactions with higher activation energy, and low temperatures those with lower activation energy [50]. However, in this study, results indicated that when reaction temperature was increased from 50 to $60^{\circ} \mathrm{C}$, biodiesel yield mostly decreased (from $86 \%$ to $76 \%$ with $700 \mathrm{rpm}$ stirring speed and $4 \mathrm{~h}$ reaction time, and from $87 \%$ to $76 \%$ with $800 \mathrm{rpm}$ stirring speed and $5 \mathrm{~h}$ reaction time, for example). Indeed, with a reaction temperature close to the boiling points of methanol and $n$-hexane, the methanol and $n$-hexane would partially vaporize and form some bubbles, which would restrain the reaction. This phenomenon was already observed during preparation of biodiesel from J. curcas oil produced by two-phase solvent extraction [47]. A reaction temperature of $50{ }^{\circ} \mathrm{C}$ for in situ transesterification of jatropha oil from seed led to the best biodiesel yields, and the highest one $(87 \%$ with a fatty acid methyl ester purity of $99.7 \%$ ) was obtained with $800 \mathrm{rpm}$ stirring speed, $50{ }^{\circ} \mathrm{C}$ temperature, and $5 \mathrm{~h}$ reaction time.

Generally, reaction time is an important factor that affects alkali-catalyzed in situ transesterification, and triglyceride conversion increases at longer reaction time $[23,25,29,30,47]$. Nevertheless, within the 3-5 h reaction time investigated in this study, increasing this parameter did not systematically increase the biodiesel yield, as previously reported by Ozgul-Yucel and Turkay [51]. Instead, biodiesel yield remained relatively constant as the reaction time increased from 3 to $5 \mathrm{~h}$, meaning that the equilibrium composition had already been achieved by the system after only $3 \mathrm{~h}$. Normally, biodiesel yield reaches a maximum as reaction time increases (e.g. at a value less than $90 \mathrm{~min}$ for transesterification of isolated and refined vegetable oils), and then remains relatively constant with any further increase [23]. Moreover, a reaction time that is too long will lead to a reduction in the biodiesel yield, due to reverse transesterification reactions. A previous study [29] has shown that the alkali-catalyzed in situ transesterification reaction from sunflower seeds is extremely fast, requiring only 20 min for complete conversion.

In transesterification reactions, reactants initially form a two phase liquid system [50]. The reaction is diffusion-controlled, and poor diffusion between the two phases results in a slower rate. As methyl esters are formed, they act as a co-solvent for the reactants and a single phase system is formed. When the single phase is established, the mixing effect is insignificant and reaction rate is primarily influenced by reaction temperature. In this study, stirring speed did not affect the biodiesel yield, and this remained rela- tively constant as the stirring speed increased from 700 to $900 \mathrm{rpm}$, meaning that the lowest stirring speed of $700 \mathrm{rpm}$ was sufficient to efficiently mix up the reactants before the establishment of the single phase.

For all the reaction conditions tested, the biodiesel quality was satisfactory (Table 2). The acid value and the viscosity remained stable at less than $0.5 \mathrm{mg}$ of $\mathrm{KOH} / \mathrm{g}$ of biodiesel and less than 3.6 $10^{-6} \mathrm{~m}^{2} / \mathrm{s}$, respectively. The saponification value was high (more than $190 \mathrm{mg}$ of $\mathrm{KOH} / \mathrm{g}$ of biodiesel), and these qualities favor its use as automotive diesel, and conform to the Indonesian Biodiesel Standard [39].

ANOVA applied to actual acid and saponification values ( $F$-test at $p=0.05$ ) shows that temperature significantly affected them, while stirring speed and reaction time had no significant effect. The same tendency was previously observed for biodiesel yield, meaning that reaction conditions had exactly the same effect on both biodiesel yield and biodiesel quality.

ANOVA applied to actual viscosity data (F-test at $p=0.05$ ) shows that stirring speed, temperature and reaction time did not significantly affect viscosity. Biodiesel viscosity remained relatively constant when stirring speed, temperature and reaction time increased.

The residual oil and fatty acid methyl ester contents in the cake meal were high (more than $11 \%$, cf. Table 2 ). Although this quality was a disadvantage for direct utilization of the cake meal, it can be converted into usable energy by combustion, gasification or pyrolysis [52,53], or transformed into agromaterials [54-59].

The analysis of the biodiesel produced by solvent extraction and in situ transesterification of jatropha oil from seed under optimal reaction conditions $(6: 1$ methanol to seed ratio, $0.075 \mathrm{~mol} / \mathrm{L} \mathrm{KOH}$ in methanol, $800 \mathrm{rpm}$ stirring speed, $50^{\circ} \mathrm{C}$ temperature, and $5 \mathrm{~h}$ reaction time) indicated that the product met the standard specification for biodiesel fuel in most regards (Table 3). Even if its cetane number (47) did not meet the Indonesian Biodiesel Standard specification (51 min) [39], it met the specification of ASTM D 6751 (47 min) [60].

\section{Conclusion}

This study showed that a new application for simultaneous solvent extraction and in situ transesterification of jatropha oil from seeds has been successfully carried out, and was a promising alternative technology for biodiesel processing from jatropha seeds. Biodiesel yield was $87 \%$ under the optimal reaction conditions with a FAME purity of $99.7 \%$. Most of the quality of biodiesel produced 
from such conditions conformed to the Indonesian Biodiesel Standard. The process flexibility would allow different oilseeds to be treated and other co-solvents to be used. Moreover, the process compactness, its flexibility, and the lack of interdependence between the oil extraction from oilseeds and the transesterification of the extracted oil allow seed treatment capacities which are lower than those of the conventional method. These lower capacities could be adapted for treatment of local oilseed production, especially concerning specific varieties, to increase the added value of the oilseeds.

\section{References}

[1] Gubiz GM, Mittelbach M, Trabi M. Exploitation of the tropical oil seed plant Jatropha curcas L. Bioresour Technol 1999;67:73-82.

[2] Openshaw K. A review of Jatropha curcas: an oil plant of unfulfilled promise. Biomass Bioenergy 2000;19:1-15.

[3] Kumar A, Sharma S. An evaluation of multipurpose oil seed crop for industrial uses (Jatropha curcas L.): a review. Ind Crops Prod 2008;28:1-10.

[4] Achten WMJ, Verchot L, Franken YJ, Mathijs E, Singh VP, Aerts R, et al. Jatropha biodiesel production and use. Biomass Bioenergy 2008;32:1063-84.

[5] Haas W, Mittelbach M. Detoxification experiments with the seed oil from Jatropha curcas L. Ind Crops Prod 2000;12:111-8.

[6] Emil A, Zahira Y, Siti Kartom K, Manal I, Jumat S. Characteristic and composition of Jatropha curcas oil seed from Malaysia and its potential as biodiesel feedstock. Eur J Sci Res 2009;29:396-403.

[7] Shivani P, Khushbu P, Faldu N, Thakkar V, Shubramanian RB. Extraction and analysis of Jatropha curcas L. seed oil. Afr J Biotechnol 2011;10:18210-3.

[8] Campbell EJ. Sunflower oil. J Am Oil Chem Soc 1983;60:387-92.

[9] Johnson LA, Lusas EW. Comparison of alternative solvents for oils extractions. J Am Oil Chem Soc 1983;60:229-42.

[10] Wan PJ, Pakarinen DR, Hron RJ, Richard OL, Conkerton EJ. Alternative hydrocarbon solvents for cottonseed extraction. J Am Oil Chem Soc 1995; $72: 653-9$

[11] Conkerton EJ, Wan PJ, Richard OA. Hexane and heptane as extraction solvents for cottonseed: a laboratory-scale study. J Am Oil Chem Soc 1995;72:963-5.

[12] Proctor A, Bowen DJ. Ambient-temperature extraction of rice bran oil with hexane and isopropanol. J Am Oil Chem Soc 1996;73:811-3.

[13] Hu W, Wells JH, Tai-Shun S, Godber JS. Comparison of isopropanol and hexane for extraction of vitamin $\mathrm{E}$ and oryzanols from stabilized rice bran. J Am Oil Chem Soc 1996;73:1653-6.

[14] Isobe S, Zuber F, Uemura K, Noguchi A. A new twin-screw press design for oil extraction of dehulled sunflower seeds. J Am Oil Chem Soc 1992;69:884-9.

[15] Guyomard P. Study of the use of a twin-screw extruder in pressing-extrusion of oleagineous seeds. $\mathrm{PhD}$ thesis. Université Technologique de Compiègne; 1994

[16] Bouvier JM, Guyomard P. Method and installation for continuous extraction of a liquid contained in a raw material; 1997. [PCT/FR97/00696].

[17] Lacaze-Dufaure C, Leyris J, Rigal L, Mouloungui Z. A twin-screw extruder for oil extraction: I. Direct expression of oleic sunflower seeds. J Am Oil Chem Soc 1999;76:1073-9.

[18] Amalia Kartika I, Pontalier PY, Rigal L. Oil extraction of oleic sunflower seeds by twin-screw extruder: influence of screw configuration and operating conditions. Ind Crops Prod 2005;22:207-22.

[19] Amalia Kartika I, Pontalier PY, Rigal L. Extraction of oleic sunflower oil by twinscrew extruder: Screw configuration and operating conditions effects. Bioresour Technol 2006;97:2302-10.

[20] Amalia Kartika I, Pontalier PY, Rigal L. Twin-screw extruder for oil processing of sunflower seeds: thermo-mechanical pressing and solvent extraction in a single step. Ind Crops Prod 2010;32:297-304.

[21] Karleskind A. Oils and fats manual, vol. 1. Paris: Lavoisier TEC \& DOC; 1996.

[22] Ma F, Hanna MA. Biodiesel production: a review. Bioresour Technol 1999;70:1-15.

[23] Leung DYC, Wu X, Leung MKH. A review on biodiesel production using catalyzed transesterification. Appl Energy 2010;87:1083-95.

[24] Harrington KJ, d'Arcy-Evans C. Transesterification in situ of sunflower seed oil. Ind Eng Chem Prod Res Dev 1985;24:314-8.

[25] Haas MJ, Scott KM, Marmer WN, Foglia TA. In situ alkaline transesterification: an effective method for the production of fatty acid esters from vegetable oils. J Am Oil Chem Soc 2004;81:83-9.

[26] Haas MJ, McAloon AJ, Yee WC, Foglia TA. A process model to estimate biodiesel production costs. Bioresour Technol 2006;97:671-8.

[27] Siler-Marinkovic S, Tomasevic A. Transesterification of sunflower oil in situ. Fuel 1998;77:1389-91.
[28] Ozgul-Yucel S, Turkay S. FA monoalkylester from rice bran oil by in situ transesterification. J Am Oil Chem Soc 2003;81:81-4.

[29] Georgogianni KG, Kontominas MG, Pomonis PJ, Avlonitis D, Gergis V. Conventional and in situ transesterification of sunflower seed oil for the production of biodiesel. Fuel Process Technol 2008;89:503-9.

[30] Qian J, Wang F, Liu S, Yun Z. In situ alkaline transesterification of cottonseed oil for production of biodiesel and nontoxic cottonseed meal. Bioresour Technol 2008;99:9009-12.

[31] Shuit SH, Lee KT, Kamaruddin AH, Yusup S. Reactive extraction and in situ esterification of Jatropha curcas L. seeds for the production of biodiesel. Fuel 2010;89:527-30.

[32] Hincapié G, Mondragón F, López D. Conventional and in situ transesterification of castor seed oil for biodiesel production. Fuel 2011;90:1618-23.

[33] NF V 03-909. Oilseeds: determination of moisture and volatile matter content (simplified method). AFNOR; 1988.

[34] NF V 03-908. Oilseeds: determination of oil content (alternative method). AFNOR; 2009.

[35] NF T 60-204. Animal and vegetable fats and oils: determination of acid value and acidity. AFNOR; 1999.

[36] SNI. Food and beverages analysis procedures. Jakarta: Badan Standarisasi Nasional; 1998.

[37] AOCS. Official methods and recommended practises. 5th ed. Illinois: American Oil Chemists' Society; 1998.

[38] AOAC. Official method of analysis of analitycal chemistry. Washington (DC): Association of Official Analytical Chemists; 1995.

[39] SNI 04-7182-2006. Biodiesel. Jakarta: Badan Standarisasi Nasional; 2006.

[40] Amalia Kartika I, Yuliani S, Ariono D, Sugiarto. In situ transesterification of jatropha seeds: effect of moisture content and particle size on yield and quality of biodiesel 2011;31:342-9 [AGRITECH].

[41] Becker K, Makkar HPS. Jatropha curcas: a biodiesel source for tomorrow's oil and biodiesel. Lipid Technol 2008;20:104-7.

[42] Foidl N, Foidl GG, Sanchez M, Mittelbach M, Hackel S. Jatropha curcas as a source for the production of biofuel in Nicaragua. Bioresour Technol 1996;58:77-82.

[43] Taub IA, Singh RP. Food storage stability. New York: CRC Press; 1998.

[44] Canakci M, Gerpen JV. Biodiesel from oils and fats with high free fatty acids. Trans Am Soc Automot Engine 2001;44:1429-36.

[45] Amalia Kartika I, Yuliani S, Kailaku SI, Rigal L. Moisture sorption behavior of jatropha seed (Jatropha curcas) as a source of vegetable oil for biodiesel production. Biomass Bioenergy 2012;36:226-33.

[46] Zeng J, Wang X, Zhao B, Sun J, Wang Y. Rapid in situ transesterification of sunflower oil. Ind Eng Chem Res 2009;48:850-6.

[47] Qian J, Shi H, Yun Z. Preparation of biodiesel from Jatropha curcas L. oil produced by two-phase solvent extraction. Bioresour Technol 2010;101:7025-31.

[48] Sharma YC, Singh B, Upadhyay SN. Advancements in development and characterization of biodiesel: a review. Fuel 2008;87:2355-73.

[49] Lu H, Liu Y, Zhou H, Yang Y, Chen M, Liang B. Production of biodiesel from Jatropha curcas L. oil. Comput Chem Eng 2009;33:1091-6.

[50] Noureddini H, Zhu D. Kinetic of transesterification of soybean oil. J Am Oil Chem Soc 1997;74:1457-63.

[51] Ozgul-Yucel S, Turkay S. Variable affecting the yields of methyl esters derived from in situ esterification of rice bran oil. J Am Oil Chem Soc 2002:79:611-4.

[52] Yorgun S, Sensöz S, Koçkar ÖM. Flash pyrolysis of sunflower oil cake for production of liquid fuels. J Anal Appl Pyrol 2001;60:1-12.

[53] Gerçel HF. The production and evaluation of bio-oils from the pyrolysis of sunflower-oil cake. Biomass Bioenergy 2002;23:307-14.

[54] Leyris J, Silvestre F, Rigal L, Gaset A. Procédé de fabrication d'objets à partir de matière première végétale par formage ou thermoformage; 1998 [FR 2784 047].

[55] Gueguen J, Viroben G, Noireaux P, Subirade M. Influence of plasticizer and treatment on the properties of film from pea proteins. Ind Crops Prod 1998;7:149-57.

[56] Orliac O, Rouilly A, Silvestre F, Rigal L. Effects of various plasticizers on the mechanical properties, water resistance and aging of thermo-moulded films made from sunflower proteins. Ind Crops Prod 2003;18:91-100.

[57] Rouilly A, Orliac O, Silvestre F, Rigal L. New natural injection-moldable composite material from sunflower oil cake. Bioresour Technol 2006;97:553-61.

[58] Evon Ph, Vandenbossche V, Pontalier PY, Rigal L. Thermo-mechanical behavior of the raffinate resulting from the aqueous extraction of sunflower whole plant in twin-screw extruder: manufacturing of biodegradable agromaterials by thermo-pressing. Adv Mater Res 2010;112:63-72.

[59] Evon Ph, Vandenbossche V, Pontalier PY, Rigal L. The twin-screw extrusion technology, an original and powerful solution for the biorefinery of sunflower whole plant Oléagineux. Corps Gras Li 2010;17:404-17.

[60] Knothe G. Analyzing biodiesel: standards and other methods. J Am Oil Chem Soc 2006;83:823-33. 